\title{
Comparative Analysis of Surface Urban Heat Island Effect in Central Sydney
}

\author{
Ehsan Sharifi ${ }^{1} \&$ Steffen Lehmann ${ }^{2}$ \\ ${ }^{1}$ Zero Waste Research Centre for Sustainable Design and Behaviour (sd+b), School of Art, Architecture and \\ Design, University of South Australia, Adelaide, Australia \\ ${ }^{2}$ School of Built Environment, Curtin University, Perth, Australia \\ Correspondence: Ehsan Sharifi, School of Art, Architecture and Design, University of South Australia, Adelaide, \\ Australia. Tel: 61-8-8302-0422. E-mail: ehsan.sharifi@unisa.edu.au
}

Received: March 14, 2014 Accepted: April 8, 2014 Online Published: April 16, 2014

doi:10.5539/jsd.v7n3p23 URL: http://dx.doi.org/10.5539/jsd.v7n3p23

\begin{abstract}
The Urban Heat Island (UHI) effect can result in higher urban densities being significantly hotter (frequently more than $4{ }^{\circ} \mathrm{C}$, even up to $10{ }^{\circ} \mathrm{C}$ ) compared to their peri-urban surroundings. Such artificial heat stress increases the health risk of spending time outdoors and boosts the need for energy consumption, particularly for cooling during summer. Urban structure, land cover and metabolism are underlined as key contributors in city scale. Under question is which urban configurations can make urban precincts and their microclimates more resilient to the surface layer Urban Heat Island (sUHI) effect?

The City of Sydney is increasingly experiencing the UHI effect due to its numerous urban development projects and changes in climate. In the Sydney context, this ongoing research aims to explore the most heat resilient urban features at precinct scale. It covers five high density precincts in central Sydney and is based on a nocturnal remote-sensing thermal image of central Sydney taken on 6 February 2009. Comparing the surface temperature of streetscapes and buildings' rooftops (dominant urban horizontal surfaces), indicates that open public spaces and particularly streetscapes are the most sensitive urban elements to the sUHI effect. The correlations between street network intensity, open public space plot ratio, urban greenery plot ratio and sUHI effect is being analysed in Sydney's high density precincts. Results indicate that higher open space plot ratio and street network intensity correlate significantly to higher sUHI effect at precinct scale. However, higher urban greenery plot ratio can effectively mitigate the sUHI effect in high density precincts.
\end{abstract}

Keywords: urban heat island effect, urban greenery, public space surface, streetscape, heat stress, Sydney

\section{Introduction}

Cities are anticipated to accommodate up to $70 \%$ of the global population by 2050 (DESA, 2012). Compared to the current urbanization rate of 50\%, almost all the expected global population growth will be accommodated in cities. Such rapid urbanization means higher densities in existing cities and many more new urban areas to accommodate up to 2 billion new urban dwellers. However, rapid urban development in fast-growing cities tends to overlook the environmental and social aspects of urban life (Girardet, 2008; Lehmann, 2010; Register, 2002). A considerable amount of natural landscape is transformed into building mass and hard surfaces, creating environmental threats for existing and future cities.

With huge demands for natural resources (i.e. energy, food, water and materials) cities are contributing up to $80 \%$ of greenhouse gas (GhG) emissions, resulting in global warming (UNECE, 2011; UNHS, 2011). Climate change projections indicate a likely increase of 2 to $5{ }^{\circ} \mathrm{C}$ in Australian surface temperature by 2050 (CSIRO, 2007; OECD, 2010). Such an increase in temperature will have a severe impact on natural ecosystems and human life in cities, including public health and quality of public space (Guest et al., 1999; Stone, 2012).

Cities also suffer from the effect of an additional form of heat, known as the Urban Heat Island (UHI) effect. This human-made heat is trapped in the built environment's thermal mass and can result in higher densities being significantly hotter, compared to their peri-urban surroundings. The urban-rural temperature difference frequently reaches $4.0{ }^{\circ} \mathrm{C}$ and can peak at more than $10{ }^{\circ} \mathrm{C}$ (Gartland, 2008; Oke, 2006; Wong \& Yu, 2008). Such additional heat can seriously impact citizens' health and the quality of public life in cities. 
The higher density of cities can bring efficiency gains, but there is interplay between the increased risk of the urban heat island effect and higher densities, which needs to be understood. Because cities are often covered in heat-absorbing surfaces and materials, such as concrete and bitumen, they absorb and store heat (e.g. through solar radiation), making urban areas warmer than the surrounding hinterland and rural areas, especially at night time.

\section{Relevant Scholarship}

Since UHI research commenced in the early 19th century, it has been studied extensively by climate scientists and material engineers. Large-scale meteorological investigations are more likely to document the phenomenon itself and contribute mainly to understanding the behaviour of UHIs by comparing city centres and their rural surroundings (Oke, 1978, 1988; Paterson \& Apelt, 1989; Tapper, 1990). These initial studies indicate the relatively higher temperature in higher densities and city centres.

Alongside meteorological UHI research, engineering investigations of surface materials' thermodynamics have focused more on energy budgets, heat exchange and heat balance in the built environment (Ashie, Thanh $\mathrm{Ca}, \&$ Asaeda, 1999; Gartland, 2008; Harman \& Belcher, 2006; Wang, Bou-Zeid, \& Smith, 2011). Research on thermal characteristics of urban surface materials at larger scales has been advanced by the development of remote sensing methods, including satellite-based, air-borne and on-the-spot thermal imagery. The understanding of surface materials' contribution to heat balance in different layers of the atmosphere over 24 hours has been enhanced by comparative studies of surface and ambient temperatures (Gartland, 2008; Oke, 2006). Other investigations aim to model building energy flux based on materials' thermal specifications (i.e. density, thermal capacity, convection rate, reflection).

The extensive recent literature on the UHI effect indicates that the artificial increase of temperature in cities is happening because of changes in energy and water budget in the built environment (Erell, Pearlmutter, \& Williamson, 2011; Gartland, 2008; Oke, 2006; Santamouris \& Geros, 2006). This artificial temperature increase affects urban microclimates in different layers of the atmosphere, including the surface layer (buildings and land surfaces), the canopy layer (below the canopy of trees or in human scale) and the boundary layer (up to 1500 meters above the ground surface). These three layers of urban microclimates are tangled in complex climatic systems, while local air circulation in the built environment can moderate the UHI effect by mixing the air in each layer with other adjacent layers (Erell, Pearlmutter, \& Williamson, 2011). Oke (2006) argues that the UHI effect has four major contributing factors:

- Urban geometry, which alters heat exchange balance in the built environment by affecting shadow and wind patterns. It affects the exposure of materials to sunlight and the consequent heat storage in thermal mass. This complex heat radiation exchange between building mass and adjacent atmosphere can also change the intensity and patterns of airflow in urban canyons.

- Urban cover and surface materials, which affect the heat absorption and reflection time-rate in the built environment. Thermodynamic specification, colour, texture and density of materials and their exposure to sunlight can alter the heat flux in outdoor space in complex procedures.

- Urban landscape, which affects water and heat exchange balance in the built environment, compared to natural surroundings. Photosynthesis and evaporation processes in urban greenery contribute to decrease the ambient temperature. Urban greenery typology, distribution and intensity also affect lower atmospheric air turbulence.

- Urban metabolism and anthropogenic (human made) waste heat in cities, which is mainly related to mass energy consumption for indoor air-conditioning and motorized transportation (see Figure 1).

Existing approaches to the UHI effect are more likely to focus on large scale monitoring and mitigation strategies or micro scale material science. More research on the key contributors to the surface layer UHI (sUHI) effect at precinct scale can provide useful links between UHI investigations at city and material scales.

The temperature of some Australian cities, such as Sydney, Melbourne and Adelaide, is already up to $4{ }^{\circ} \mathrm{C}$ warmer than surrounding areas. The current investigation discusses ongoing research on the City of Sydney, which is an example of a city facing an increasing UHI effect due to its post-19th century urban development. Due to the city's sub-tropical climate and the UHI effect, public spaces in the city are already warmer in summer than humans' thermal comfort, pushing citizens into air-conditioned buildings and creating an ever-increasing rise in outdoor temperatures. Such artificial urban heat stress increases the mortality rate, especially of the elderly (Hu, Becker, McMichael, \& Tong, 2007). The aim is to investigate the most effective sUHI mitigation strategies at the precinct scale in Sydney. 


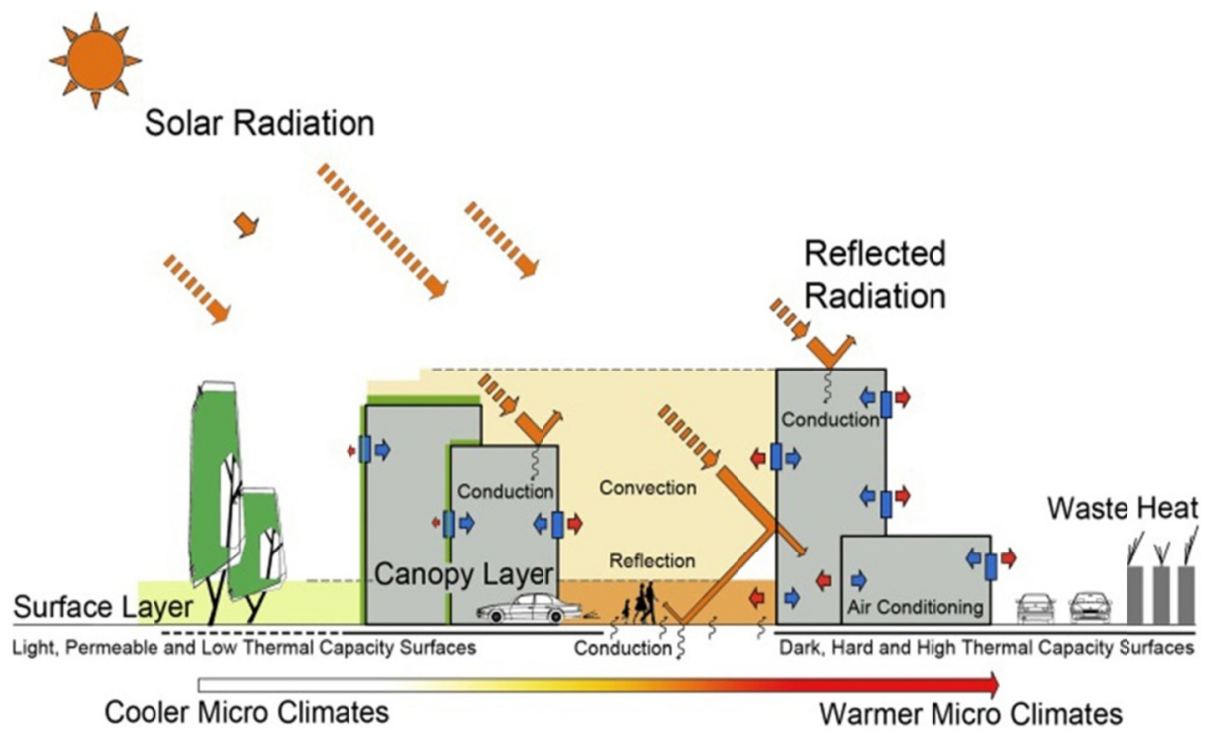

Figure 1. Urban structure, landscape, land-cover and metabolism contribute to the Urban Heat Island effect in cities

\section{Methods and Materials}

Although major UHI contributors may be present in a wide range of regional climates, the effectiveness of urban features on the UHI effect is highly contextual (Oke, 2006; Wong \& Yu, 2008). For example, the UHI effect's behaviour in the canopy layer of a sub-tropical city like Sydney in summer differs from drier climates, due to generally higher humidity and lower day-night temperature variations. The high dependence of UHI research on geographical, climatic and structural contexts highlights the need for climate-specific UHI case studies to achieve applicable research outcomes.

The City of Sydney has experienced significant development since 1945 (Toon \& Falk, 2003), which continues in the 21st century (McGuirk, 2003). Sydney has also experienced five severe heat waves: in 1939, 2004, 2007 (Australian Bureau of Meteorology, 2008), 2009 and 2012. Heat waves are becoming more frequent and last for longer in recent years. The maximum air temperature of $46{ }^{\circ} \mathrm{C}$ on 18 January 2013 surpasses the highest temperature recorded, of $43{ }^{\circ} \mathrm{C}$ on 6 February 2009. Facing the UHI effect, the City of Sydney has facilitated a number of UHI investigations based on remote sensing thermal imagery over the past decade, concluding with a Building Thermal Performance Index (BTPI) to evaluate buildings' envelope thermal behavior (Samuels, Randolph, Graham, McCormick, \& Pollard, 2010). However, the BTPI is for individual buildings and is not applicable to the precinct or city scale.

The current research focuses on the surface layer UHI (sUHI) effect, which studies the surface temperature of horizontal urban features. Utilizing the literature on the UHI effect, thermal imagery, GIS information and image processing, this study aims to investigate the correlations between the urban greenery ratio, open space ratio and the surface temperature in five precincts in central Sydney. Aerial thermal photography of central Sydney was conducted on 6 February 2009 by Digital Mapping Australia for the City of Sydney, available with the resolution of 8 meters. The resulting remote-sensing maps indicate different surface temperatures in central Sydney. Building and population densities, open space and urban greenery primary data are based on GIS information provided by the City of Sydney. Spatial dimension, plot ratio and distribution of open space and urban greenery are extracted from a Google Earth image dated 4 February 2009 (to match the data to the thermal imagery of 6 February 2009).

On 5 February 2009 , the temperature reached $31{ }^{\circ} \mathrm{C}$ at $6 \mathrm{pm}$ with a relative humidity of $33 \%$. During the night, wind speed was less than $5 \mathrm{~m} / \mathrm{s}$, which was unable to cool down the city by the next morning. Consequently on the 6 February 2009, the air temperature reached the high record of $43^{\circ} \mathrm{C}$ at $7 \mathrm{pm}$ with a relative humidity of $10 \%$ and wind speed of less than $5 \mathrm{~m} / \mathrm{s}$. This heat stress continued in Sydney on 7 February with a maximum temperature of $39^{\circ} \mathrm{C}$ at $6 \mathrm{pm}$ and a relative humidity of $12 \%$. Due to higher humidity in lower temperatures, the real feeling of the (apparent) temperature did not come below $30^{\circ} \mathrm{C}$ on 6 and 7 February. According to Thom's Discomfort Index (Moran, Laor, Epstein, \& Shapiro, 1998; Thom, 1959) and Human Heat Index (ASHRAE, 2004), the micro climate condition in Sydney during the target days was partly in 'heavy discomfort' and mostly 
in 'emergency discomfort' zones, which can cause heatstroke, especially for elderly and disadvantaged people (Kovats \& Hajat, 2008).

Thermal imagery of central Sydney on 6 February 2009 maps different surface temperatures of the built environment. It also provides the average surface temperatures of ten precincts (urban districts with identifiable characters), which shape different temperature zones inside central Sydney. From these precincts, five higher density precincts have been selected for the current research. Sydney Harbor, Haymarket, Harris Street, Kings Cross and Glebe Point are being compared to investigate which urban features can be most effective in reducing the sUHI effect in high density precincts of Sydney.

\subsection{Preliminary Observation}

According to the map of temperature zones, the Haymarket precinct had the hottest surface temperature with an average of $31.03{ }^{\circ} \mathrm{C}$, while the overall surface temperature in Sydney Harbor precinct was $30.88{ }^{\circ} \mathrm{C}$, in Harris Street $30.95^{\circ} \mathrm{C}$, in Kings Cross $30.34{ }^{\circ} \mathrm{C}$ and in Glebe Point $30.65^{\circ} \mathrm{C}$ (see Figure 2).

Although the temperature variance is only $0.69{ }^{\circ} \mathrm{C}$, it can be considered significant, because each average temperature is the mean of over 2000 data points. Furthermore, in this thermal map the average surface temperature of central Sydney is only $30.56{ }^{\circ} \mathrm{C}$ (Standard Deviation $=0.26$ ). The temperature variance among the Kings Cross (min average) and Haymarket (max average) precincts is $0.69^{\circ} \mathrm{C}$. However, smaller urban elements' (e.g. streetscapes and rooftops) surface temperature varies from 28 to $33{ }^{\circ} \mathrm{C}$ (see Figure 3 and Figure 4). Overlapping the surface temperature maps of individual urban elements and average precincts, indicates that the overall temperature in the Haymarket precinct $\left(31.03{ }^{\circ} \mathrm{C}\right)$ is very close to the surface temperature in the Barangaroo site $\left(31.08{ }^{\circ} \mathrm{C}\right.$. see Figure 2 centre top). At the time of this thermal mapping, Barangaroo was an industrial site fully covered by concrete (a greener redevelopment plan is underway). Concrete, along with asphalt, is among the hottest and most undesired urban surfaces identified by sUHI studies (Erell, Pearlmutter, \& Williamson, 2011; Gartland, 2008; Oke, 1988). This cross mapping reveals that the sUHI effect in Haymarket precinct is significant and intense. The questions are: what physical configurations in precinct scale contribute to this extremely hot temperature and is it possible to mitigate it?

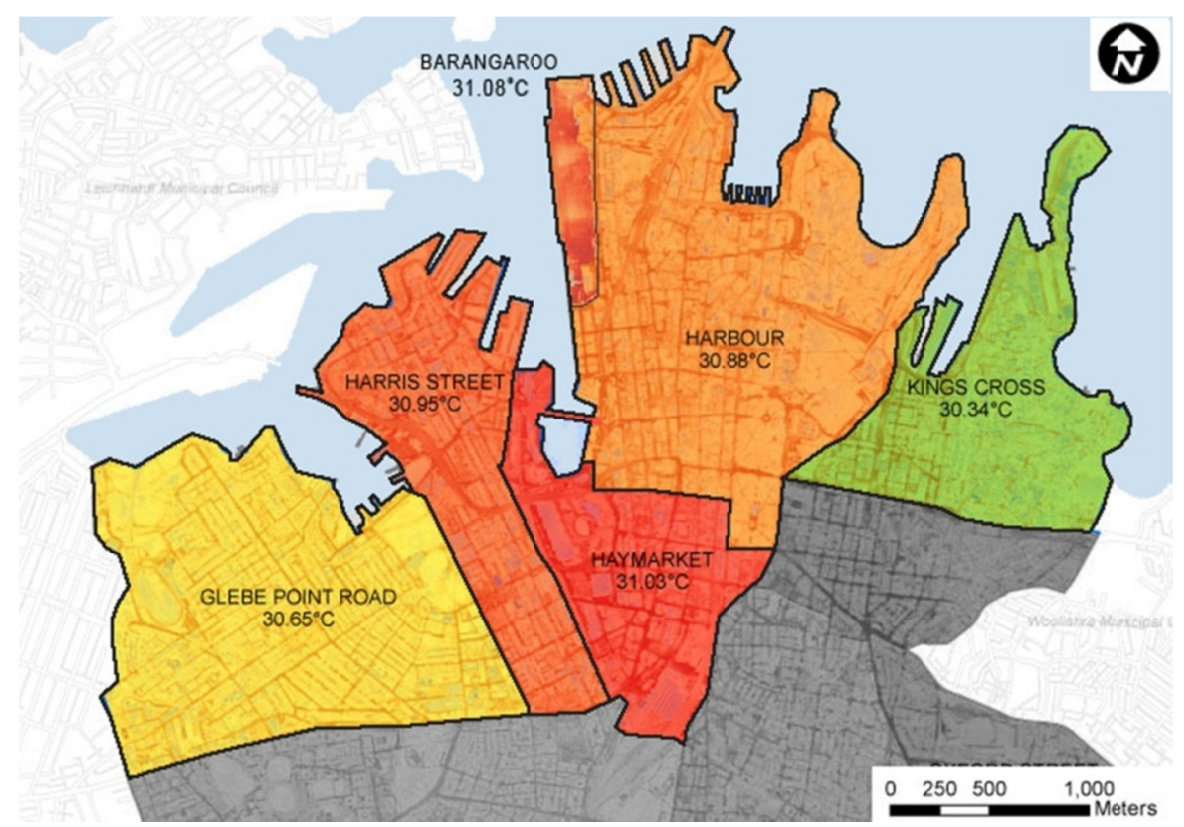

Figure 2. Average surface temperature of precincts in Glebe Point, Harris Street, Sydney Harbor, Haymarket and Kings Cross precincts

Based on: (City of Sydney, 2010).

\subsection{Controlled Variables: Residential and Building Density}

Density, the number of units/people in a given land area, is still a controversial term in urban design. Both building and urban (population) densities are being controlled in this study to enable more focused analysis on 
urban elements and features in higher densities. Discussion about the effect of building density on the magnitude of sUHI shapes a considerable portion of the urban microclimate literature (Giridharan, Ganesan, \& Lau, 2004; Lee, Holst, \& Mayer, 2013; Yuan \& Chen, 2011). Since the early sUHI studies, it has been argued that higher densities are likely to have higher temperature (Givoni, 1998; Oke, 1988; Tapper, 1990) due to their physical structure.

Background sUHI research indicates that high density building blocks can magnify the sUHI effect in cities by increasing the opportunity for surface materials to absorb direct and reflected sunlight radiation (Erell, Pearlmutter, \& Williamson, 2011; Giridharan, Lau, Ganesan, \& Givoni, 2007; Priyadarsini, 2009). Generally, reflected solar radiation has more chance to exit the built environment in lower densities and less compact areas (Wong \& Yu, 2008). During each reflection phase between building facades and street surfaces, a portion of solar energy is transmitted into built environment surfaces in the form of heat (Erell, Pearlmutter, \& Williamson, 2011). Thus the general surface temperature is likely to be higher in higher densities. The five selected precincts have a building density of more than 100 units per acre (Sydney Harbor and Haymarket have up to 200 units per acre). According to Campoli and MacLean's (2007) classification of building density, over 100 units per acre can be considered as very high building density.

Higher building density can also intensify energy consumption in cities and consequently increase anthropogenic waste heat (Ichinose, Matsumoto, \& Kataoka, 2008; Sivam \& Karuppannan, 2012). Although population density is not a direct contributor to the UHI effect, it can increase the need for energy consumption for air conditioning and transport. Citizens in higher densities consume a considerable amount of energy in their daily life, especially for indoor air-conditioning and transportation. This higher rate of energy consumption increases the amount of anthropogenic (human-made) waste heat in higher densities and therefor contributes to the UHI effect in cities. However, a clear link between anthropogenic waste heat and sUHI has not been identified yet.

Central Sydney has the highest population density in Australia with an estimated residential population of 180,679 residents living in an area of $4.48 \mathrm{~km}^{2}$ in 2010 (City of Sydney, 2011). The overall urban density of the City of Sydney is $40330 \mathrm{p} / \mathrm{km}^{2}$. However, the five selected sites represent a higher average urban density of over $74136 \mathrm{p} / \mathrm{km}^{2}$. Therefore, the selected case studies have very high urban densities compared to other Australian cities and even other precincts in central Sydney. However, the number of people visiting central Sydney on a daily basis for shopping, entertainment and education reaches up to 483,000. This is in addition to the 385,000 people who arrive every day to work in central Sydney. The considerable proportion of temporary residents compared to permanent dwellers (more than fourfold) makes it difficult to consider residential density as a factor, contributing to the sUHI effect in Sydney. Furthermore, population density is usually discussed regarding to ambient temperature UHI effect, while the current study focusses on the surface layer Urban Heat Island (sUHI) effect. As such the variable of population density is being controlled in the current study.

\section{Analysis and Results}

Urban features can influence the surface temperature in higher densities by affecting the overall rate of materials' exposure to sunlight and heat exchange between them (ASHRAE, 2004; Oke, 2006). Specific heat capacity, conductivity and albedo (reflectivity) of materials are the most affective factors, which can cause the built environment to store sunlight energy in the form of heat in its thermal mass and to postpone the energy departure process from the built environment (Ashie, 2008; Dahl, 2010; Oke, 1988). Still the location of materials needs to be carefully considered, as shading can influence the heat absorption and reflection process significantly. Two of the most common places, where the sUHI is being discussed are urban open space (including streetscapes and public space) and buildings' rooftops.

\subsection{Thermal Behaviour of Horizontal Surfaces of Streetscapes and Rooftops}

Comparison between surface temperatures of different horizontal urban features can indicate which elements are more heat-sensitive and therefore need more examination in sUHI mitigation studies. Comparing 300 randomly selected data points indicates that a higher temperature exists on streetscape surfaces rather than building rooftops (see Figure 3 and Figure 4). The average temperature of streetscape surface layer is $31.39{ }^{\circ} \mathrm{C}$, which is $0.37^{\circ} \mathrm{C}$ higher than the Haymarket precinct overall surface temperature (the hottest precinct in Figure 2). Some streetscape surfaces, especially in the Haymarket precinct, reached the highest temperature of $34.15{ }^{\circ} \mathrm{C}$ with $5.10{ }^{\circ} \mathrm{C}$ variance from the minimum streetscape temperature (see Table 1). The average surface temperature of buildings' rooftop layer is $30.26{ }^{\circ} \mathrm{C}$ (with the maximum value of $33.61{ }^{\circ} \mathrm{C}$ ), which is $1.13{ }^{\circ} \mathrm{C}$ less than the average streetscape surface temperature, $0.77^{\circ} \mathrm{C}$ less than the average temperature of the Haymarket precinct, $0.69{ }^{\circ} \mathrm{C}$ less than the Harris Street, $0.62{ }^{\circ} \mathrm{C}$ less than the Sydney Harbor and $0.39{ }^{\circ} \mathrm{C}$ less than Glebe Point (the rooftop layer average surface temperature is very close to Kings Cross average surface temperature: $30.34{ }^{\circ} \mathrm{C}$ ). 


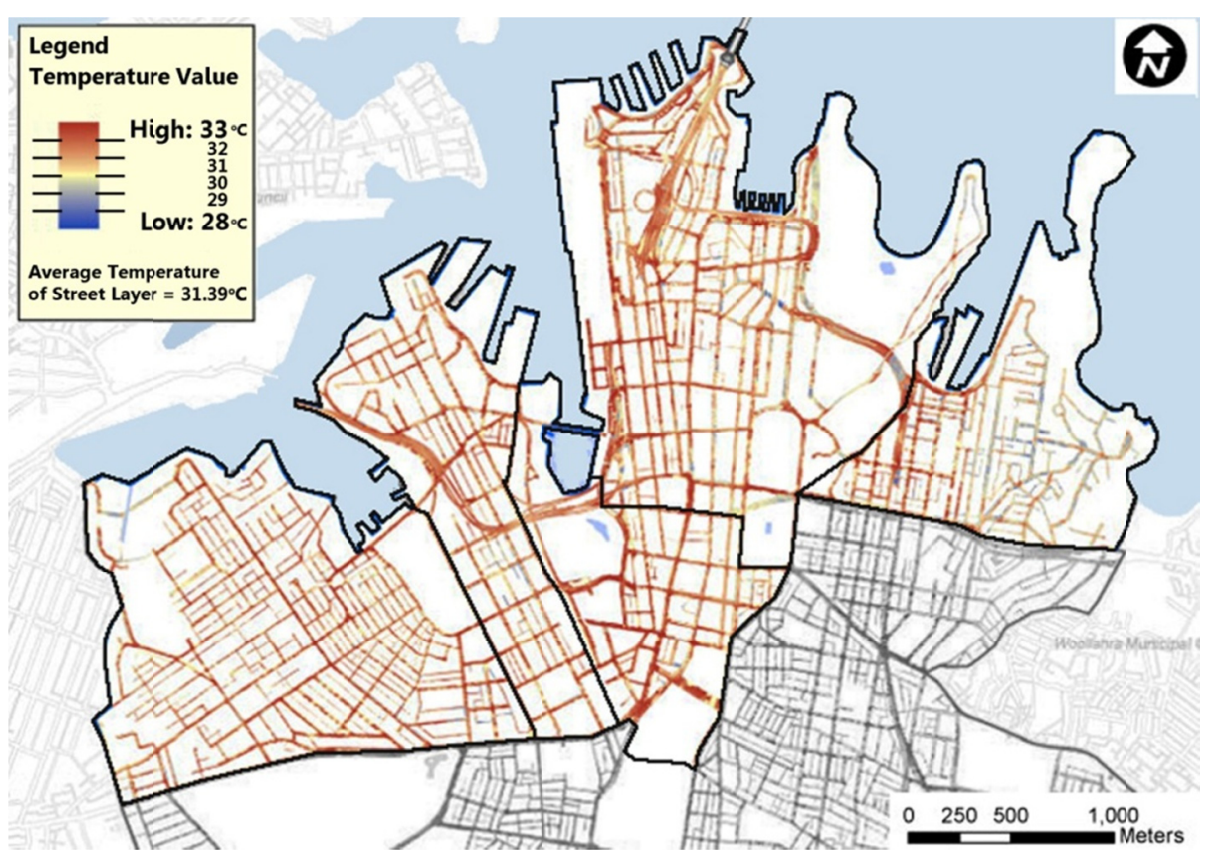

Figure 3. Street surface temperature in five adjacent high density precincts in central Sydney Based on: (City of Sydney, 2010).

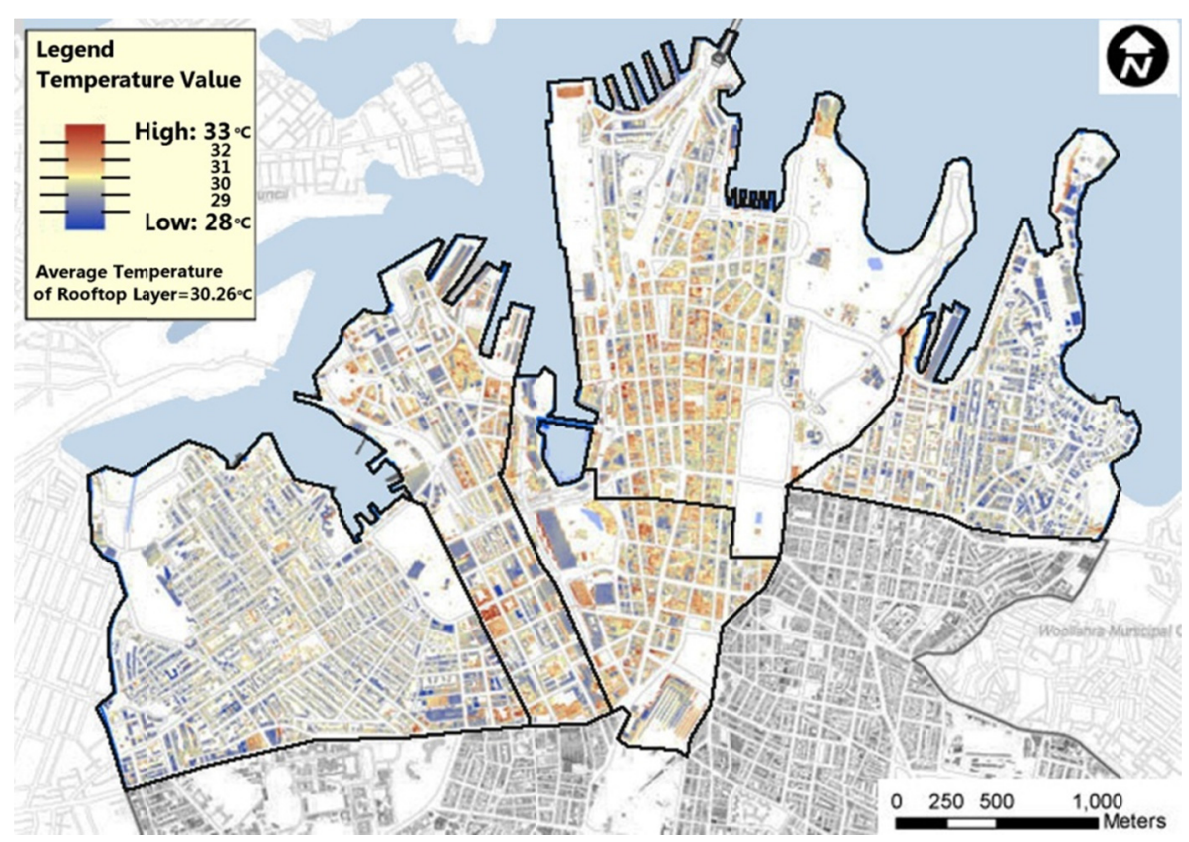

Figure 4. Rooftop surface temperature in in five adjacent high density precincts in central Sydney Based on: (City of Sydney, 2010).

According to Table 1 the streetscape has a considerably higher surface temperature and temperature variance than do building rooftops. This underlines the streetscape as the more heat-sensitive urban feature at precinct scale. To undertake more detailed sUHI analysis, the street network intensity is compared against open public space plot ratio. 
Table 1. Temperature variance of streetscape surfaces and building rooftops in five high density precincts of central Sydney

\begin{tabular}{ccccc}
\hline & Min Temp. $\left({ }^{\circ} \mathrm{C}\right)$ & Max Temp. $\left({ }^{\circ} \mathrm{C}\right)$ & Average Temp. $\left({ }^{\circ} \mathrm{C}\right)$ & Temp. variance $\left({ }^{\circ} \mathrm{C}\right)$ \\
\hline Streetscape & 29.05 & 37.30 & 31.15 & 8.25 \\
Building rooftop & 27.70 & 33.61 & 30.26 & 5.91 \\
Temp Variance & 2.65 & 3.69 & 0.89 & 2.24 \\
(Street-Roof) & & & & \\
\hline
\end{tabular}

\subsection{Correlation between Open Space Plot Ratio, Street Network Intensity, Public Space Plot Ratio and the sUHI Effect}

As heat-sensitivity is more in between buildings rather than their rooftops, it is worthwhile to analyse further the correlations between the open space general land use and the sUHI effect. Therefore, the streetscape and public space are being analysed separately in this section. This correlation analysis can indicate to what degree the sUHI effect is a dependent variable of streetscape or public space plot ratio. Table 2 shows that street network intensity (streetscape plot ratio) has the correlation coefficient (R) value of +0.94 to the average precinct surface temperature. It means that a higher streetscape plot ratio indicates almost directly to the higher overall surface temperatures in Sydney precincts. This high and positive coefficient value indicates that higher streetscape surfaces can strongly correlate with the sUHI effect in precinct scale (the maximum R value can be 1, which shows complete correlation).

The open space plot ratio (i.e. all hard-landscaped open spaces including streetscapes and other public spaces) has even more coefficient value of +0.97 to overall surface temperature in Sydney precincts. This high coefficient value indicates strong correlation of overall surface temperate to the proportion of hard-landscaped open space (e.g. paved with concrete and asphalt). However, separating other open spaces from the streetscape results in a relatively lower coefficient value of +0.64 between the hard-landscaped public space plot ratio and the precinct surface temperature, which still indicates a higher correlation than average (moderate $\mathrm{R}$ value is $+0.5)$.

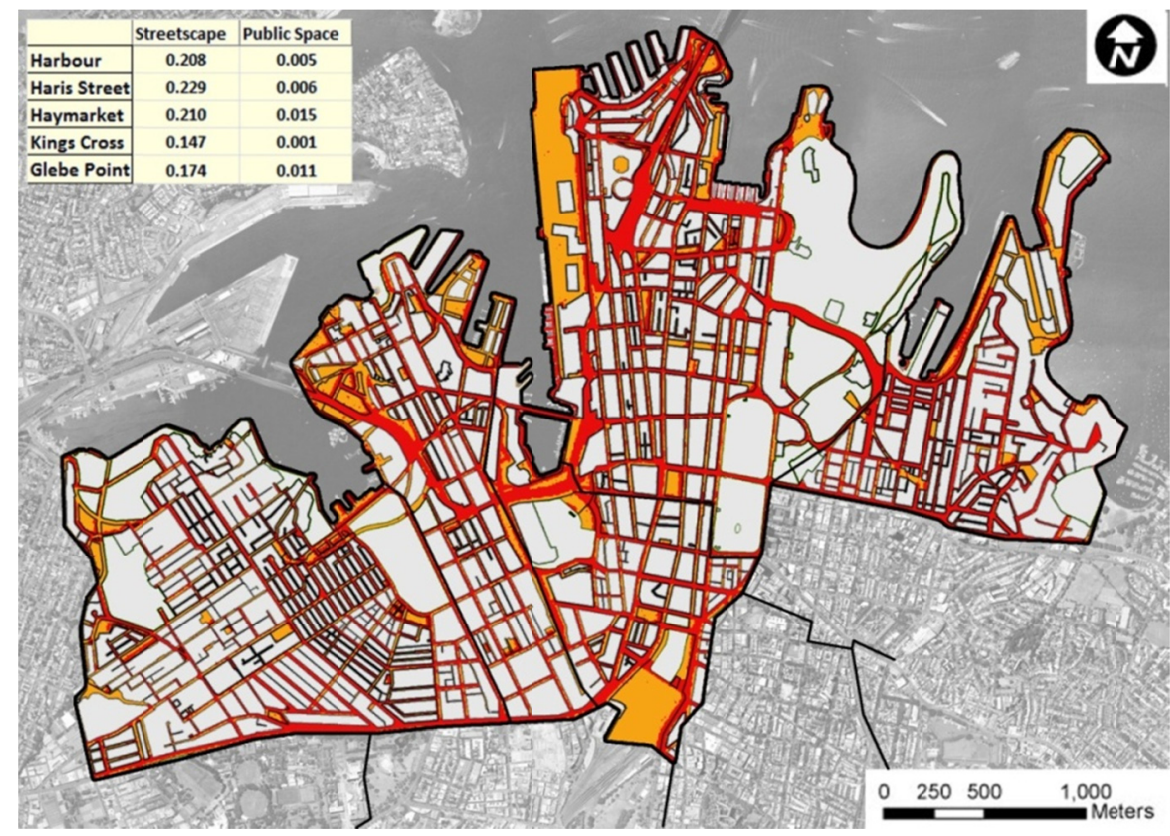

Figure 5. Streetscape and public space plot ratio in five precincts of Sydney

Feature Extraction from Google Earth Imagery 2009, resolution: 1 meter. 
Table 2. Street network intensity and average surface temperature in the five precincts of central Sydney

\begin{tabular}{cccccc}
\hline Precinct & Sydney Harbor & Harris Street & Haymarket & Kings Cross & Glebe Point \\
\hline $\begin{array}{c}\text { Street network plot ratio } \\
\text { (per cent) }\end{array}$ & $20.8 \%$ & $22.9 \%$ & $21.0 \%$ & $14.7 \%$ & $17.4 \%$ \\
$\begin{array}{c}\text { Open space plot ratio } \\
\text { (per cent) }\end{array}$ & $21.3 \%$ & $23.5 \%$ & $22.4 \%$ & $12.8 \%$ & $18.5 \%$ \\
$\begin{array}{c}\text { Public space plot ratio } \\
\text { (other than streetscape) }\end{array}$ & $0.5 \%$ & $0.6 \%$ & $1.5 \%$ & $0.1 \%$ & $1.1 \%$ \\
$\begin{array}{c}\text { Average Surface } \\
\text { Temperature }\left({ }^{\circ} \mathrm{C}\right)\end{array}$ & 30.88 & 30.95 & 31.03 & 30.34 & 30.65 \\
\hline
\end{tabular}

High and positive coefficient values between hard-landscaped open spaces (i.e. streetscape and public space layers) and sUHI on-the-ground surface layer indicates that harder landscapes can effectively increase the surface temperature of urban precincts. Under question is whether there are any urban land covers capable of mitigating the sUHI effect at precinct scale?

\subsection{Correlation Between Urban Greenery Plot Ratio and the sUHI Effect}

An extensive amount of literature supports the idea that greenery can mitigate the sUHI effect (Ashie, 2008; Butera, 2008; Correa, Ruiz, Canton, \& Lesino, 2012; Dahl, 2010; Erell, Pearlmutter, \& Williamson, 2011; Gartland, 2008; Oke, 2006). At the micro scale, this heat mitigation occurs in two ways: first, through using solar energy and photosynthesis to facilitate greenery metabolism and second, through evapotranspiration (evaporative cooling) in reaction to the ambient heat on the surface of leaves (just like human skin). Therefore, green infrastructures can counteract the sUHI effect by cooling down air and surface temperatures in micro scale.

Various forms of greenery can exist in urban precincts, such as parklands, gardens, green roofs, vertical greenery, urban farming, nature reserves and planting of extensive vegetation; all acting as sources of moisture for evapotranspiration, where the absorbed solar radiation can be dissipated as latent heat and thus aid in reducing urban temperature. Recent research by Wong (2008) shows that vegetated spaces could be a few degrees cooler than their surroundings. Under question is to what extent this is applicable at precinct scale? To investigate the effect of urban greenery on sUHI mitigation at precinct scale, Urban Greenery Plot Ratio (UGPR) is being compared to the sUHI effect in the five Sydney precincts.

The total study area (the five precincts selected) covers $1.75 \mathrm{~km}^{2}$, which includes an overall area of $0.36 \mathrm{~km}^{2}$ of urban greenery (UGPR=20.7\%). However, there is a significant variance in urban UGPR in the five selected precincts. As shown in Table 3, UGPR is 26.6\%in Sydney Harbor and 29.1\% in Glebe Point. However, UGPR in Kings Cross is $11.2 \%$, in Harris Street $7.69 \%$ and in Haymarket only $3.31 \%$. Significant variance of UGPR and proximity of these precincts make them appropriate cases to study further.

Table 3. Urban vegetation ratio in the five precincts of Sydney Central

\begin{tabular}{cccccc}
\hline Precinct & Sydney Harbor & Harris Street & Haymarket & Kings Cross & Glebe Point \\
\hline Urban Greenery $\left(\mathrm{km}^{2}\right)$ & 0.15 & 0.03 & 0.01 & 0.04 & 0.12 \\
Precinct Area $\left(\mathrm{km}^{2}\right)$ & 0.58 & 0.25 & 0.20 & 0.25 & 0.47 \\
$\begin{array}{c}\text { Urban Greenery Plot } \\
\text { Ratio (UGPR) }\end{array}$ & $26.6 \%$ & $12.4 \%$ & $6.7 \%$ & $17.8 \%$ & $25.3 \%$ \\
$\begin{array}{c}\text { Average Surface } \\
\text { Temperature }\left({ }^{\circ} \mathrm{C}\right)\end{array}$ & 30.88 & 30.95 & 31.03 & 30.34 & 30.65 \\
\hline
\end{tabular}

With the correlation coefficient $(\mathrm{R})$ value of -0.40 for precincts and -0.78 for smaller random sample areas (120 samples are studied, each with the exact area of $100 \mathrm{~m}^{2}$ ), precinct surface temperature shows medium to high dependency to UGPR. This also indicates that the effect of UGPR on sUHI is moderated by other factors at larger scales. 


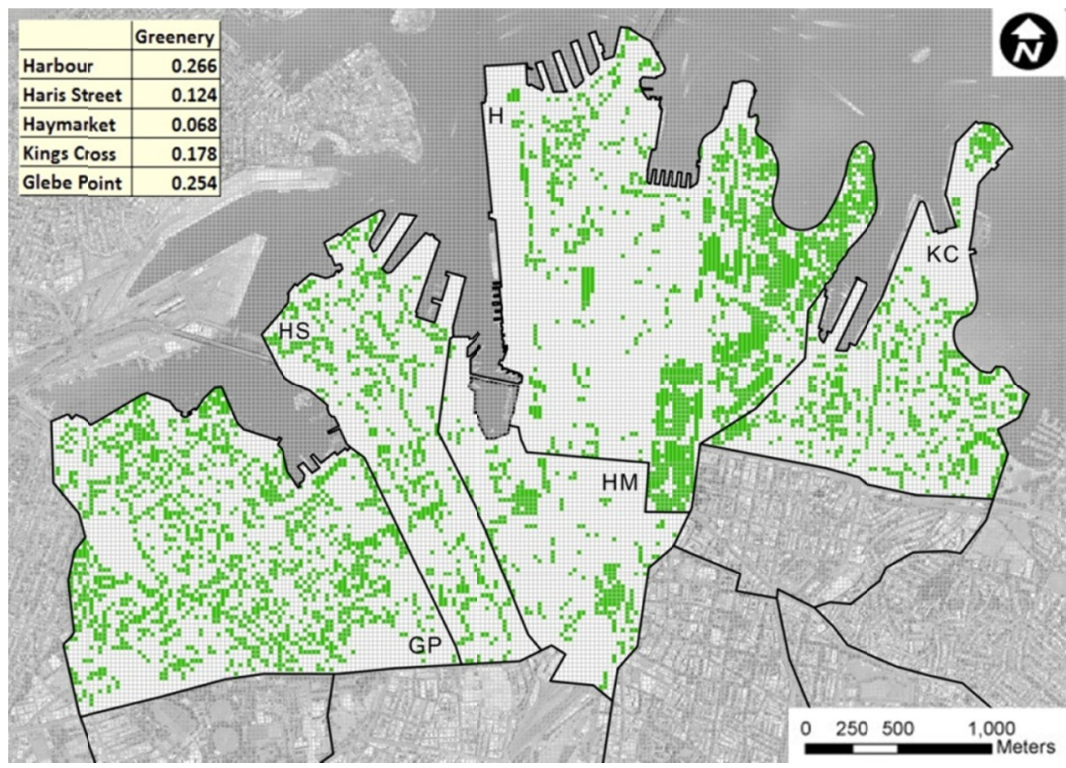

Figure 6. Urban vegetation ratio in five precincts of Sydney

Extraction from Google Earth imagery 2009, resolution: 8 meters.

Urban greenery distribution in Figure 6 reveals that Kings Cross and Glebe Point (the lowest average surface temperature) have the most homogenous urban greenery distribution, while hot Haymarket has the lowest and scattered greenery spots. In the Sydney Harbor precinct, the large area of the Royal Botanic Gardens and Hyde Park can explain its relatively lower sUHI compared to Haymarket and Harris Street.

\section{Further Discussion}

The surface temperature zones map (Figure 2) of central Sydney shows that Haymarket precinct has the highest surface temperature with an average of $31.03{ }^{\circ} \mathrm{C}$. The overall surface temperature of the Haymarket precinct is very close to the surface temperature of extremely hot urban features in the study area (e.g. $31.08{ }^{\circ} \mathrm{C}$ in Barangaroo and $31.15{ }^{\circ} \mathrm{C}$ for average streetscape layer). This means that sUHI in the Haymarket precinct is significantly higher (mathematically) than central Sydney's average $\left(30.56^{\circ} \mathrm{C}\right)$, which highlights Haymarket is the most vulnerable precinct to the sUHI effect. Comparing streetscape surface temperatures (Figure 3 ) and urban greenery distribution (Figure 6) reveals that the sUHI effect is more in less vegetated areas. Although all five precincts have high building densities, streetscape surfaces in Sydney Harbor are up to $1.6^{\circ} \mathrm{C}$ cooler than similar areas in Haymarket. This relative coolness correlates with the higher rate of UGPR in the Sydney Harbor (19.9\% higher than Haymarket).

Overall, the surface temperature of open space and rooftops is slightly more in the Sydney Harbor and Haymarket precincts (with twice the building density of the other three precincts). This could be due to the lower Sky View Factor (i.e. the amount of sky visible from the surface) for streetscapes. It needs to be noted that the rooftops of high rise buildings in Haymarket and Sydney Harbor and partly in Harris Street are flat roofs, whereas the rooftops in Kings Cross and Glebe Point are a combination of flat roofs and pitched roofs, which have different solar gain due to the way they face solar radiation (i.e. in the southern hemisphere, horizontal surfaces generally have more daily solar gain than surfaces sloped towards the south, east and west). For an in-depth discussion about streetscape and rooftops' surface temperature, more detailed data about land cover surface materials is needed.

A comparison between Figure3, Figure4 and Table 1 reveals that streetscape surfaces are generally hotter than rooftops (up to $3.69{ }^{\circ} \mathrm{C}$ ). Rooftops are exposed to sunlight radiation almost all day long, while street canyons have partial shadow coverage due to surrounding high-rise buildings. Therefore, in theory, rooftops should gain more heat compared to streetscape surfaces, but in practice streetscapes have the hotter surfaces. In the current study, streetscape surfaces represent a higher minimum temperature $\left(2.65{ }^{\circ} \mathrm{C}\right)$, higher maximum temperature $\left(3.69^{\circ} \mathrm{C}\right)$ and higher average temperature $\left(0.89^{\circ} \mathrm{C}\right)$ than rooftops, as well as more surface temperature variance $\left(2.24^{\circ} \mathrm{C}\right)$. This indicates the importance of focusing on cooler land covers and urban greenery on-the-ground surface layer rather than on rooftops in the central Sydney. 
The higher ratio of urban greenery in the Sydney Harbor precinct (UFPR=26.6\%) compared to Haymarket (6.7\%) and Harris Street (12.4\%) seems to be the most effective factor in mitigating the sUHI effect in precinct scale. A significant area of urban greenery in the Royal Botanic Gardens and Hyde Park (located in the Sydney Harbor precinct, see Figures 2, 6) is cooling down the precinct's overall surface temperature.

\section{Conclusion}

Urban temperatures are predicted to increase due to climate change. The temperatures in our cities are likely to increase further, because more heat will be stored and re-radiated by expanses of asphalt, concrete and other heat-storing building materials. In this context, it is crucial to understand the possibilities for the transformation of existing urban fabrics towards a more liveable and sustainable future (Bosselmann, 2008; Lehmann, 2010). This can be implemented by smart and small-scale spatial transformation of existing urban spaces.

The basic argument underlined in this comparative case study is that the higher sUHI effect in precinct scale correlates with more hard-landscaped public space plot ratio, more street network intensity and less urban greenery plot ratio. Higher open space plot ratio and street network intensity correlate significantly to higher sUHI effect at precinct scale. However, higher urban greenery plot ratio can mitigate the sUHI effect in high density precincts. Therefore, increasing urban greenery and decreasing hard-landscaped urban features (e.g. streetscapes and vast hard-covered open spaces) can cool down existing precincts. A fine distribution of urban greenery can also mitigate the sUHI at precinct scale.

\section{Research Limitations and Further Opportunities}

This research is based on remote sensing thermal photography and desktop spatial data. It utilizes the surface temperature which is different from the real feeling of the temperature in public space. Further studies could benefit also from on-the-spot microclimate measurements and air temperature data. The effect of local airflow and surface water is subject to further investigation. To move towards more certainty about the research outcomes, on-the-spot microclimate measurement in smaller scales of the built environment such as specific public spaces, building blocks or streetscapes could be beneficial. Simulation of wind turbulence and heat exchange of different urban structures and landscapes can facilitate research in smaller scales. Due to the limited scope of this study and controlled variables, the results need to be tested further in other cities.

\section{Acknowledgments}

This paper draws on the work of the authors at the Zero Waste Research Centre for Sustainable Design \& Behaviour ( $\mathrm{sd}+\mathrm{b}$ Centre) at the University of South Australia, and the UNESCO Chair in Sustainable Urban Development for Asia and the Pacific. It is a part of an ongoing research project on urban microclimates of Australian cities, supported by the CRC for Low Carbon Living and the cities of Sydney, Melbourne and Adelaide. The authors acknowledge the generosity of the City of Sydney for providing thermal maps and GIS data, which facilitated this research.

\section{References}

Ashie, Y. (2008). Management of Urban Heat Environment. In Urban Environmental Management and Technology (Vol. 1, pp. 215-238). Tokyo: Springer Japan. http://dx.doi.org/10.1007/978-4-431-78397-8_12

Ashie, Y., Thanh Ca, V., \& Asaeda, T. (1999). Building Canopy Model for the Analysis of Urban Climate. Journal of Wind Engineering and Industrial Aerodynamics, 81, 237-248. http://dx.doi.org/10.1016/S0167-6105(99)00020-3

ASHRAE. (2004). Standard 55 - Thermal Environmental Conditions for Human Occupancy. Atlanta: ASHRAE Inc.

Australian Bureau of Meteorology. (2008). Climate of Australia. Melbourne: Commonwealth of Australia.

Bosselmann, P. (2008). Urban Transformation: Understanding City Design and Form. Washington DC: Island Press.

Butera, F. (2008). Towards the Renewable Built Environment. In D. Peter (Ed.), Urban Energy Transition: From Fussil Fuels to Renewable Power (pp. 329-364). Amsterdam: Elsevier. http://dx.doi.org/10.1016/B978-0-08-045341-5.00014-1

City of Sydney (Cartographer). (2010). Thermal Imagery.

City of Sydney (Cartographer). (2011). Residential Monitor. 
Correa, E., Ruiz, M. A., Canton, A., \& Lesino, G. (2012). Thermal Comfort in Forested Urban Canyons of Low Building Density. An Assessment for the City of Mendoza, Argentina. Building and Environment, 58, 219-230. http://dx.doi.org/10.1016/j.buildenv.2012.06.007

CSIRO. (2007). Climate Change in Australia: Technical Report 2007. Aspendale VIC: CSIRO and Australian Bureau of Meteorology.

Dahl, T. (2010). Climate and Architecture. Milton Park: Routledge.

DESA. (2012). World Urbanization Prospects: The 2011 Revision. New York: United Nations.

Erell, E., Pearlmutter, D., \& Williamson, T. (2011). Urban Microclimate: Designing the Spaces between Buildings. London: Earthscan.

Gartland, L. (2008). Heat Islands: Understanding and Mitigating Heat in Urban Areas. Washington, DC: Earthscan.

Girardet, H. (2008). Cities People Planet: Liveable Cities for a Sustainable World. Chichester: John Wiley \& Sons.

Giridharan, R., Ganesan, S., \& Lau, S. S. Y. (2004). Daytime Urban Heat Island Effect in High-rise and High-density Residential Developments in Hong Kong. Energy \& Buildings, 36(6), 525-534. http://dx.doi.org/10.1016/j.enbuild.2003.12.016

Giridharan, R., Lau, S., Ganesan, S., \& Givoni, B. (2007). Urban Design Factors Influencing Heat Island Intensity in High-rise High-density Environments of Hong Kong. Building and Environment, 42(10), 3669-3684. http://dx.doi.org/10.1016/j.buildenv.2006.09.011

Givoni, B. (1998). Climate Considerations in Building and Urban Design. New York: Van Nostrand Reinhold.

Guest, C. S., Willson, K., Woodward, A. J., Hennessy, K., Kalkstein, L. S., Skinner, C., \& McMichael, A. J. (1999). Climate and Mortality in Australia: Retrospective Study, 1979-1990, and Predicted Impacts in Five Major Cities in 2030. CLIMATE RESEARCH, 13(1), 1-15. http://dx.doi.org/10.3354/cr013001

Harman, I. N., \& Belcher, S. E. (2006). The Surface Energy Balance and Boundary Layer over Urban Street Canyons. Quarterly Journal of the Royal Meteorological Society, 132(621), 2749-2768. http://dx.doi.org/10.1256/qj.05.185

Hu, W., Becker, N., McMichael, T., \& Tong, S. (2007). Heat-related Mortality during Summer in Sydney, Australia, 1990-2004. Epidemiology, 18(5), S113-S114.

Ichinose, T., Matsumoto, F., \& Kataoka, K. (2008). Counteracting Urban Heat Islands in Japan. In D. Peter (Ed.), Urban Energy Transition: From Fussil Fuels to Renewable Power (pp. 365-380). Amsterdam: Elsevier. http://dx.doi.org/10.1016/B978-0-08-045341-5.00015-3

Kovats, R. S., \& Hajat, S. (2008). Heat Stress and Public Health: a Critical Review. Annual Review of Public Health, 29(1), 41-55. http://dx.doi.org/10.1146/annurev.publhealth.29.020907.090843

Lee, H., Holst, J., \& Mayer, H. (2013). Modification of Human-Biometeorologically Significant Radiant Flux Densities by Shading as Local Method to Mitigate Heat Stress in Summer within Urban Street Canyons. Advances in Meteorology, 2013. http://dx.doi.org/10.1155/2013/312572

Lehmann, S. (2010). The Principles of Green Urbanism: Transforming the City for Sustainability. Washington, DC: Earthscan.

MacLean, A. S., \& Campoli, J. (2007). Visualizing Density. Cambridge, Mass. Lincoln Institute of Land Policy.

McGuirk, P. (2003). Planning Central Sydney. In A. MacLaran (Ed.), Making Space: Property Development and Urban Plannin (pp. 118-147). London: Hodder Arnold

Moran, D. S., Laor, A., Epstein, Y., \& Shapiro, Y. (1998). A Modified Discomfort Index (MDI) as a Substitute for the Wet Bulb Globe Temperature (WBGT). Medicine \& Science in Sports \& Exercise, 30(Supplement), 284. http://dx.doi.org/10.1097/00005768-199805001-01614

OECD. (2010). Cities and Climate Change: Organisation for Economic Cooperation and Development (OECD).

Oke, T. R. (1978). Boundary Layer Climates. New York: Wiley. http://dx.doi.org/10.4324/9780203407219

Oke, T. R. (1988). The Urban Energy Balance. Progress in Physical Geography, 12(4), 471-508. http://dx.doi.org/10.1177/030913338801200401 
Oke, T. R. (2006). Towards Better Scientific Communication in Urban Climate. Theoretical and Applied Climatology, 84(1), 179-190. http://dx.doi.org/10.1007/s00704-005-0153-0

Paterson, D. A., \& Apelt, C. J. (1989). Simulation of Wind Flow around 3-Dimensional Buildings. Building and Environment, 24(1), 39-50. http://dx.doi.org/10.1016/0360-1323(89)90015-2

Priyadarsini, R. (2009). Urban Heat Island and its Impact on Building Energy Consumption. Advances in Building Energy Research, 3(1), 261-261. http://dx.doi.org/10.3763/aber.2009.0310

Register, R. (2002). Ecocities: Building Cities in Balance with Nature. Berkeley, Calif: Distributed by Publishers Group West.

Samuels, R., Randolph, B., Graham, P., McCormick, T., \& Pollard, B. (2010). Micro-Urban-Climatic Thermal Emissions in a Medium-Density Residential Precinct. Sydney: University of New South Wales.

Santamouris, M., \& Geros, V. (2006). Environmental Design of Urban Buildings: An Integrated Approach. Sterling: Earthscan.

Sivam, A., \& Karuppannan, S. (2012). Density, Design and Sustainable Residential Development. In S. Lehmann \& R. Crocker (Eds.), Designing for Zero Waste: Consumption, Technologies and the Built Environment (pp. 267-283). New York and London: Earthscan

Stone, B. (2012). CITY and the Coming Climate: Climate Change in the Places we Live. New York: Cambridge University Press. http://dx.doi.org/10.1017/CBO9781139061353

Tapper, N. J. (1990). Urban Influences on Boundary-Layer Temperature and Humidity - Results from Christchurch, New-Zealand. Atmospheric Environment Part B-Urban Atmosphere, 24(1), 19-27. http://dx.doi.org/10.1016/0957-1272(90)90005-F

Thom, E. C. (1959). The Discomfort Index. Weatherwise, 12(2), 57-61. http://dx.doi.org/10.1080/00431672.1959.9926960

Toon, J., \& Falk, J. (Eds.). (2003). Sydney: Planning or Politics: Town Planning for Sydney Region Since 1945. Sydney: Planning Research Centre, University of Sydney.

UNECE. (2011). Climate Neutral Cities: How to Make Cities Less Energy and Carbon Intensive and more Resilient to Climatic Challenges. New York and Geneva: United Nations Economic Commission for Europe.

UNHS. (2011). Cities and Climate Change: Global Report on Human Settlements 2011. London: United Nations Human Settlements Programme, Earthscan.

Wang, Z.-H., Bou-Zeid, E., \& Smith, J. A. (2011). A Spatially-Analytical Scheme for Surface Temperatures and Conductive Heat Fluxes in Urban Canopy Models. Boundary-Layer Meteorology, 138(2), 171-193. http://dx.doi.org/10.1007/s10546-010-9552-6

Wong, N. H., \& Yu, C. (2008). Tropical Urban Heat Islands: Climate, Buildings and Greenery. New York: Taylor $\&$ Francis

Yuan, C., \& Chen, L. (2011). Mitigating Urban Heat Island Effects in High-density Cities Based on Sky View Factor and Urban Morphological Understanding: A Study of Hong Kong. Architectural Science Review, 54(4), 305. http://dx.doi.org/10.1080/00038628.2011.613644

\section{Copyrights}

Copyright for this article is retained by the author(s), with first publication rights granted to the Journal of Sustainable Development.

This is an open-access article distributed under the terms and conditions of the Creative Commons Attribution license (http://creativecommons.org/licenses/by/3.0/). 